DE DE GRUYTER OPEN G

Maciej Dębski

University of Social Sciences
Journal of Intercultural Management

Vol. 6, No. 4, December 2014, pp. 39-54

DOI 10.2478/joim-2014-0034

\title{
Tourism habits and preferences - comparative analysis in selected European countries
}

\begin{abstract}
Tourism is an important sector of the economy, which is responsible for the development of many regions, which generates millions of jobs and allows to operate several businesses. However, it must be remembered that the motives of the trips are strongly differentiated, which translates into the existence of many types of tourism and diversification of tourism products. As a consequence, it becomes necessary to conduct permanent monitoring of attitudes, motives and consumers behaviors in order to adapt the offer to their preferences. In the article, the author, presenting the specificity of tourism shows the results of the study dedicated to selected tourist behaviors of Polish, Ukrainian and Austrian students. Even, if the limitations of the study will be accepted, it provides evidence for positive verification of the hypothesis that the significant differences between these groups exist.
\end{abstract}

Key-words: tourism, consumer behaviours, tourism product

\section{Introduction}

Tourism is a significant element of the economy worldwide; for numerous regions or countries it serves as an important source of income, setting the stage for development. S. Bosiacki even writes that "tourism in the 21 st century has become one of the most powerful sectors of the global economy, having tremendous importance for the transformation process, a form of spending leisure time for millions of people." (Bosiacki S. et al. 2008, pp. 53-54). Whereas K. Hannam and D. Knox highlight that tourism has become a key issue in supranational, national and regional development programmes (2010, p20). Yet, J. Kaczmarek, A. Stasiak, B. Włodarczyk refer to the example of the fuel industry or cutting-edge technologies bringing the focus to comparability of income generated (2010, p. 9).

*mdebski@spoleczna.pl 
Quotations implying the remarkable significance of tourism may proliferate. After all, these opinions are validated by the facts. According to data provided by the World Tourism Organization the economic sector discussed tends to account for $9 \%$ of global GDP, generating $10 \%$ workplace and making up a total of $6 \%$ of the global export. Furthermore, 2013 saw 1087 million international tourist arrivals (as compared to 25 million in 1950) and domestic arrivals spanning from 5 up to 6 billion (UNWTO...2014, p. 2). Across the European Union an average share of tourism in GDP is estimated at around 5\% (Panasiuk A, 2014, p. 21).

Tourism generates income, though it is also closely connected with other economic sectors, thereby profoundly affecting them, and thus revealing its weight as well as its specifics. The World Tourism Organization recommends to include 10 from among 17 economic sectors into the broadly understood tourism economy (Meyer B., 2008, p. 16). Such an extensive approach to the visitor economy results from the essential aspects of tourism, which emanate from the specifics of the tourism product.

The strong role played by tourism in present day economy makes it expedient to seek any possibilities for stimulating its growth. Analysing consumer behaviour preferences tends to be one of the elements of enhancing competitiveness across tourist regions. The study presented falls into this field. The objective set by the author is to examine selected elements of behaviour related to tourism consumption among three groups of students: Polish, Ukrainian and Austrian. Accomplishment of the objective entailed establishing a research hypothesis addressing significant differences occurred among three groups surveyed. The paper structure appeared to the consequence of the objective and hypothesis set. In its theoretical part, the author attempted to give an insight into specifics of the tourism product, which then affects tourists' behaviour. The empirical part of the paper reveals the findings from the survey questionnaire conducted in 2014 among three students' groups previously indicated.

\section{Tourism products and tourists - their essence and specifics}

The literature features numerous definitions of tourism. For instance, the British Tourism Society coined a definition asserting that "tourism embraces all activities referred to the temporary, short-term movement of people to destinations outside the places where they normally live and work, and staying in these visited places" (Gaworecki W., 2007, p. 18). Over recent time prominence was given to the approach based on the recommendations of the World Tourism Organization (Terminology..., 1995, pp. 3-4). According to these guidelines, S. McCabe defines tourism as the "sum of relations and phenomena resulting from activities of persons travelling and staying outside their place of residence for not more than one consecutive year for leisure, business or other purposes" (2010, p. 2). In essence, the 
definition places a consumer-tourist at the centre of tourism who then appears to be a creator of activity and relationship, yet the approach displayed broadly addresses the motives behind travels and types of tourism activities.

What is more important for demonstrating the characteristics of tourism is exposure of the specifics inherent to a tourism product. Basically, reference literature shows two approaches to the issue. A tourism product may be regarded, in the narrow sense, as a service or goods offered by an individual entrepreneur, however for the purposes of the paper it is preferable to present a tourism product from a broad perspective as a tourism destination. To put it simply, it may be defined as any attractions and services likely to be sold to a visitor (Sung K., 2013, pp. 8-9). Whereas E. Kiralova illustrates the structure of the product in a schematic manner identifying its two spheres: a basic tourism offer completing a full tourism offer (Kiralova E., 2003, p. 88 as cited in Gryzel P., 2004 p. 25). The first comes as an result of the attractiveness of the region in which attractions were typified into three groups: environmental, anthropogenic as well as parties together with social and cultural events. It should be underlined that this part of the regional tourism product principally arouses tourists' interest in the destination, yet an urge to harness the attractions encourages them to willingly visit a specific destination. As noted by C. Vassiliadis creating attractive tourism products is crucial for stability of the local, national and European economies (2008, p. 440).

Meanwhile, a complementary tourism offer, which is the other component of the tourism region's product, come as the benefit of the infrastructure present in the area and determines the convenience of staying, and thus largely consumer satisfaction. It is relatively easy to imagine a situation when a tourist is dissatisfied with their stay and fails to give recommendations for a specific destination in the case where, despite remarkable attractiveness of the area, there are an accommodation base and restaurants that fall short of expected standards, and where it is difficult to reach a particular destination.

Core to assessing the specifics underlying a tourism product is recognition of its immense complexity, which is a component of multiple variables related to both the attractiveness as well as the services rendered across a specific area: services targeted towards a tourist. It should be stressed that particular elements of the tourism product of the destination are created by a great number of independent entities. In such a situation this becomes a product difficult to be managed, and the key to its development is close cooperation among its stakeholders which, as proven by practice, remains difficult to attain.

Management of the region's tourism product, to put it simply, may be boiled down to its creation so as to generate value to buyers, which may thus result in triggering interest in it, purchasing it and finally delivering satisfaction with the purchase. However, the complexity of the product discussed allows that its varied 
elements have diverse relevance for individual tourists, and moreover, in particular target groups there are various expectations towards the same product's elements. For instance W. Gaworecki designates 18 various types of tourism, each with its own specifics and related expectations (2007, pp. 23-88). Essentially, it is practically unlikely for destination management to fulfil all expectations, thereby impelling persons and entities charged with destination's development to make choices.

Figure 1 provides a simplified model illustrating a process of creating motivation for visiting a specific destination. J. Holloway gives priority to the consumer's needs which consequences include a perception of the means for their fulfilment as well as destination's attractions and their assessment. In the situation when a potential tourist recognises that the attractions allow for meeting their needs, the motivation to visit a destination occurs. The above model constitutes a certain simplification of the reality which was its goal, though it should be remembered that attractions as well as consumers' needs tend to be diversified, and thus it is often unlikely to attain complete compatibility. Sam J. Holloway emphasizes that frequently consumers themselves are not aware of their needs, thereby making it difficult to prepare a product for their fulfilment (2002, p. 65).

Fig. 1. Motivation process on the tourism market

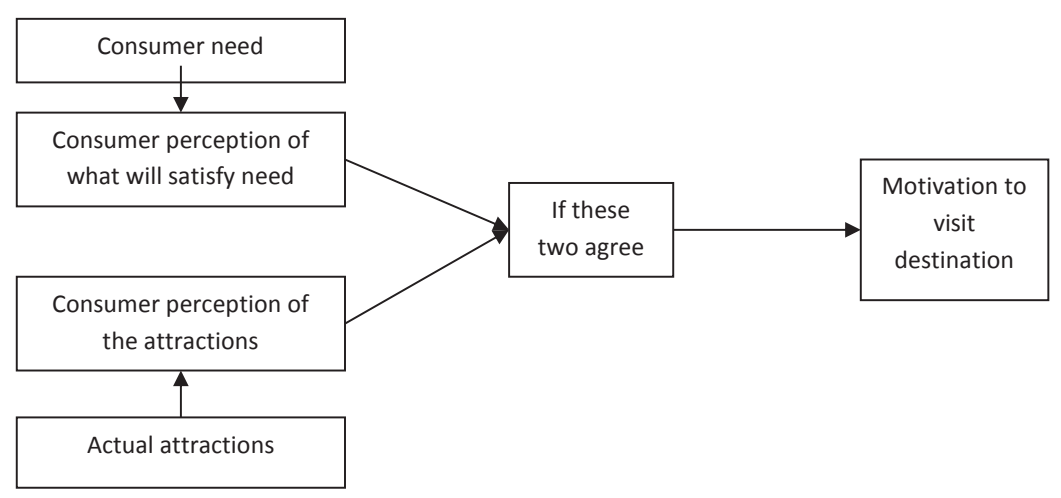

Source: J. Holloway, The business of tourism, Pearson Education, Harlow 2002, p. 66

As mentioned previously, tourism and related activities generate the demand for tourism products as they deliver specific values to clients. From the standpoint of the managing person it is important that values are highly diversified, which is closely related to the diversification of the tourism product as well motives and forms of tourism activities. Reference literature stresses that travels are driven by a wide range of factors. For example C. Cooper, J. Fletcher, D. Gilbert, S. Wanhill classify them into two groups. The first includes factors connected with a life style: income, employment, travelling opportunities, education and mobility. Whereas 
the second is an effect of the life cycle: age, household conditions or family ties (1998, p. 40 as cited in Kizielewicz J., 2014, p. 289).

From the perspective of ongoing deliberations, core to the effective tourism destination management proves to be identification of tourists' habits, preferences or motives behind their behaviour and shopping (Celtek E., 2013, p. 6). P. van der Merve, E. Slabbert and M. Saayman even argue that it becomes imperative to precede destination marketing actions with an analysis of tourists-consumers' motives. Only integration of their preferences may yield a long-lasting success (2011, p. 458). The same authors provide a fairly detailed overview of research on travelling motivating elements, and moreover they indicate preferences for travelling in one single coherent compilation: holiday, in areas valued in environmental terms, on seaside coasts, those related with events, and shopping (2011, p. 460).

\section{Methodology of research}

The study seeks to identify tourists' preferences and their consumption style, and its findings will be revealed below. A research group was represented by a specific consumer's community comprising students. An overruling objective of the study was to compare preferences among Polish and Ukrainian students as well as students from Austria. It may be assumed that student communities share certain characteristic attributes which should emerge in the style of tourism. It seems that three of them are primary:

- a student is a young person - the fact explicitly translates into preferences or consumption patterns, such a person more willingly make use of cutting-edge technologies, e.g. for communication (it needs to be considered in the marketing communication), prefers active forms of leisure, or integration with peers will be relatively of larger importance;

- a student has a large quantity of time - it is a significant quantity, but at the same time it is largely limited to semester holidays, in summer a 3-month travel is available, without being constrained with a holiday leave or work obligations, young persons have less family obligations;

- a student has a smaller budget and smaller expectations - young persons are at the beginning of their professional career paths, and thereby earning less, or they only receive funds from their parents, at the same time they attach less weight to comfort while travelling or staying.

The study covered three groups of students: Polish, Ukrainians and those in Austria. An assumption was adopted that these communities will be divrsified due to income (determining opportunities for tourism) and tourism habits. An overriding objective of the study was to identify selected preferences and purchasing behaviours across three students' groups, and the research hypothesis held that habits are diverse depending on the place and origins of the students. 
Table 1: Age and place of residency

\begin{tabular}{|l|l|l|l|}
\hline Age & Ukraine & Poland & Austria \\
\hline Below 25 years & $90 \%$ & $72 \%$ & $91 \%$ \\
\hline $25-35$ years & $7 \%$ & $16 \%$ & $9 \%$ \\
\hline $36-55$ years & $3 \%$ & $12 \%$ & $0 \%$ \\
\hline Above 55 years & $0 \%$ & $0 \%$ & $0 \%$ \\
\hline Place of residency & & & \\
\hline Country & $10 \%$ & $23 \%$ & $8 \%$ \\
\hline Town below 10.000 & $10 \%$ & $10 \%$ & $12 \%$ \\
\hline $\begin{array}{l}\text { Town } 10.000- \\
100.000 .\end{array}$ & $28 \%$ & $25 \%$ & $32 \%$ \\
\hline City above 100,000 & $52 \%$ & $42 \%$ & $50 \%$ \\
\hline
\end{tabular}

Source: Own study based on the survey completed

Ultimately the research yielded responses from 83 Polish and 42 Ukrainian students as well as 108 students from Austria, which brought the number of survey questionnaires properly completed to the total of 233. The survey conducted in the first half of 2014 among students at economic faculties. Characteristics of respondents may be an important element having an impact on the research findings. Importantly, all three groups have a structure that is internally comparative. In the case of Polish students only certain deviations may be discerned. First, percentage of persons aged below 25 is smaller, still this is a prevailing group, and a higher average age among Polish students is linked to the fact that there is a high number of part-time students in Poland, persons that enrol to studies few years after graduating school. Second, as regards Polish students, a smaller percentage indicated a big city as its place of residence, while more respondents pointed out a country. It appears that some persons indicating a country as their place of residence actually live on the outskirts of the large city, which is typical, specifically for Warsaw agglomeration where portion of the survey took place. Therefore, it may be assumed that a portion of $23 \%$ Polish respondents coming from a country reveal consumer behaviours distinctive for inhabitants of large cities, which leads to the presumption that persons surveyed share far more similar characteristics than evidenced in the compilation.

\section{Findings and conclusions}

The first question to be answered in the survey inquired about forms of using free time during tourism travels (see Table 2). To find a response to the question is particularly significant for those managing a region or a tourism company. Having realized that, marketing specialists know which information should be emphasized 
in the promoting message, and which elements of the product should be further developed so that an offer could satisfy expectations of the specific target group.

Table 2. Forms of using free time during tourism travels

\begin{tabular}{|l|l|l|l|}
\hline & Ukraine & Poland & Austria \\
\hline $\begin{array}{l}\text { Visiting museums, } \\
\text { exhibitions }\end{array}$ & $67 \%$ & $33 \%$ & $49 \%$ \\
\hline Shopping & $52 \%$ & $43 \%$ & $54 \%$ \\
\hline Attending festivals & $24 \%$ & $23 \%$ & $12 \%$ \\
\hline Relaxing on beach & $52 \%$ & $77 \%$ & $58 \%$ \\
\hline Testing local food & $62 \%$ & $72 \%$ & $73 \%$ \\
\hline Active night life & $60 \%$ & $48 \%$ & $43 \%$ \\
\hline Practising sport & $26 \%$ & $33 \%$ & $29 \%$ \\
\hline Exploring wildlife & $31 \%$ & $41 \%$ & $20 \%$ \\
\hline $\begin{array}{l}\text { Visiting historical } \\
\text { monuments }\end{array}$ & $64 \%$ & $63 \%$ & $60 \%$ \\
\hline $\begin{array}{l}\text { Participating in sport } \\
\text { events }\end{array}$ & $9 \%$ & $10 \%$ & $12 \%$ \\
\hline Buying souvenirs & $57 \%$ & $54 \%$ & $64 \%$ \\
\hline & & & \\
\hline
\end{tabular}

Source: Own study based on the survey completed

Notice: The highest scores in particular categories were bolded.

Topping the list were: visiting historical monuments, relaxing on the beach and trying local food. A high position of the last element comes as a surprise. Although culinary tourism has been gaining in popularity, it is still not a form of massive tourism. The results scored suggests that those managing tourism have to take into account this activity form. Yet definitely the lowest score was given to participation in sport events. As regards two countries hosting the Euro 2012 such an indication may take by surprise, but as the results obtained show the respondents in any country fail to follow their idols to support them on a massive scale.

It is worthwhile bringing the focus to the principal issues from the perspective of the research hypothesis adopted. It is likely to observe considerable distinctions among specific countries. Regarding Ukraine, more individuals pointed out visiting museum, exhibitions and an active night life. Whereas Polish students far more willingly relax on the beach (for this category it should be kept in mind that Austria has no access to sea) and explore wildlife. With reference to the last form reported, attention should be given to low rank in Austria, even though this is a country where wildlife attractions are central to plans for tourism expansion. Mean- 
while in this country shopping and purchase of souvenirs notched up the highest score among three groups of respondents. Principally, it seems that an upper hand, though insignificant, in this respect is the effect of higher income in Austria as compared to other states.

Selection of key factors guiding travel decisions expounds the forms of using free time. Their identification, likewise for the previous question, reveals the offer's elements to be further bolstered and emphasized in the process of communication with potential clients. Key factors for students in specific countries were detailed in Table 3.

Table 3. Assessment of factors when making travelling decisions

\begin{tabular}{|c|c|c|c|}
\hline Factor & Ukraine & Poland & Austria \\
\hline $\begin{array}{l}\text { Possibility of prac- } \\
\text { tising various sport } \\
\text { disciplines, related } \\
\text { infrastructure }\end{array}$ & 2.44 & 2,38 & 3.3 \\
\hline $\begin{array}{l}\text { Architectural build- } \\
\text { ings, museums }\end{array}$ & 3.44 & 2.79 & 3 \\
\hline $\begin{array}{l}\text { Special events, fes- } \\
\text { tivals }\end{array}$ & 3.1 & 2.83 & 2.78 \\
\hline Easy access & 3.24 & 3.77 & 3.35 \\
\hline $\begin{array}{l}\text { Presence of places of } \\
\text { religious merit }\end{array}$ & 2.27 & 1.69 & 1.5 \\
\hline $\begin{array}{l}\text { Destination brand } \\
\text { (famous, popular) }\end{array}$ & 2.85 & 2.35 & 2.32 \\
\hline $\begin{array}{l}\text { Quality of accommo- } \\
\text { dation base }\end{array}$ & 3.95 & 4.08 & 3.81 \\
\hline Travel costs & 4.24 & 4.36 & 4.25 \\
\hline $\begin{array}{l}\text { Quality and access to } \\
\text { shops }\end{array}$ & 3.56 & 3.3 & 2.85 \\
\hline $\begin{array}{l}\text { Variety of holiday-rec- } \\
\text { reation offer (swim- } \\
\text { ming pools, cinema, } \\
\text { parks, children's play- } \\
\text { grounds) }\end{array}$ & 4 & 3.78 & 3.38 \\
\hline $\begin{array}{l}\text { Quality and effective- } \\
\text { ness of local transport }\end{array}$ & 3.73 & 3.14 & 3.07 \\
\hline $\begin{array}{l}\text { Easy access to attrac- } \\
\text { tive spots }\end{array}$ & 4.15 & 4.22 & 3.22 \\
\hline Climate & 4.17 & 4.31 & 3.79 \\
\hline Quality of catering & 3.41 & 3.8 & 3.36 \\
\hline
\end{tabular}




\begin{tabular}{|l|l|l|l|}
\hline $\begin{array}{l}\text { Folk art on a specific } \\
\text { area }\end{array}$ & 3.02 & 2.14 & 2.11 \\
\hline $\begin{array}{l}\text { Natural assets (wild- } \\
\text { life) }\end{array}$ & 4 & 3.58 & 3.15 \\
\hline Clubs, theme parks & 3.88 & 3.35 & 3.10 \\
\hline
\end{tabular}

Source: Own study based on the survey conducted

Notice: Respondents assessed the significance of specific factors within the scale 1-5. The highest scores in particular categories were bolded.

It should not come as a surprise that among all communities surveyed a cost factor received the top rank. Moreover, considerable importance is attached to the quality of the accommodation base, easy access to attractive places or a factor being outside the control of destination managers - the climate. Nevertheless, the significant fact is that substantial distinctions among specific respondents' groups emerged in responses to the questions addressed, with these disparities being markedly larger than for the forms of spending leisure time during travels. Some distinctions may be ascribed to the sample size or its sampling, though differences stretched to several dozen percentage points among ratings are so considerable as to be taken into account.

First, it should be underlined that generally Polish and Ukrainian students attributed a higher importance to specific factors than students based in Austria. Merely in one case out of seventeen a did a highest rank came from this country and it was: the possibility of practising sports. It is worthwhile emphasizing the fact that that factor attained an immense advantage, which may be important information on the issues concerning spending leisure time. While Ukrainian students granted substantially higher rating for: quality and easy access to shops, quality and effectiveness of transport, wildlife assets or clubs and theme parks. These scores could suggest that this group of respondents express the highest requirements. However, as proved by the experience, requirements grow alongside the increase in income and financial potentials. Meanwhile, as said previously, Ukraine is a country reporting a lower income than Poland, and especially lower than Austria. It seems that these distinctions may be clarified in another way. Across all categories the lowest scores were granted by students in Austria. Overall, it may be assumed that higher quality standards prevail in this country as well as in students' destination countries, and thus certain product parameters may be taken for granted, and as a consequence they are not indicated as a decisive factor.

Another vital issue for the tourism are consumers buying habits, which is particularly manifested by the use of intermediaries. Information in this regard proves to be crucial from the perspective of designing distribution channels and related 
promotional activities. Responses provided by the respondents in this respect are shown in Table 4. What is surprising is that intermediaries are mostly used when booking an accommodation; based on previous analyses it could look as if preference was given to "travel packages". It should be highlighted that the question did not distinguish between national and international travels, and it may be assumed that buying habits for both travel types are dissimilar and that intermediaries play a bigger part in international tourism. Importantly, responses to the questions raised reveal distinctions between individual students' groups. Specifically, focus should be placed on the rating given by students in Austria exposing greatest use of intermediaries while booking flight tickets, and a scanty percentage of persons within the same group who would report that they always purchase travel packages. The ratings in the latter case may imply a higher independence in exercising tourism, and, besides, they are, to some extent, compensated by the highest percentage of ratings in the category "I sometimes purchase a travel package", though the ratings in the first case are hard to be explained. It is likely that direct purchase by the Internet, though with the use of global reservation systems could be regarded by some respondents as intermediary operations unlike the Polish and Ukrainian respondents. Another potential explanation, as evidenced by the respondents' travel destinations, concerns the fact that Polish and Ukrainian students travel a far shorter distances, and possibly the majority of them do not use air transport, and therefore they failed to indicate intermediary in buying a ticket.

Table 4. Use of intermediaries

\begin{tabular}{|l|l|l|l|}
\hline & Ukraine & Poland & Austria \\
\hline $\begin{array}{l}\text { I always buy flight } \\
\text { tickets through inter- } \\
\text { mediary }\end{array}$ & $14 \%$ & $8 \%$ & $29 \%$ \\
\hline $\begin{array}{l}\text { I sometimes buy flight } \\
\text { tickets through inter- } \\
\text { mediary }\end{array}$ & $19 \%$ & $22 \%$ & $44 \%$ \\
\hline $\begin{array}{l}\text { I always buy railway/ } \\
\text { bus tickets through } \\
\text { intermediary }\end{array}$ & $14 \%$ & $6 \%$ & $10 \%$ \\
\hline $\begin{array}{l}\text { I always buy a whole } \\
\text { travel package }\end{array}$ & $24 \%$ & $29 \%$ & $7 \%$ \\
\hline $\begin{array}{l}\text { I always book accom- } \\
\text { modation through } \\
\text { intermediary }\end{array}$ & $24 \%$ & $17 \%$ & $31 \%$ \\
\hline $\begin{array}{l}\text { I sometimes book } \\
\text { accommodation } \\
\text { through intermediary }\end{array}$ & $38 \%$ & $26 \%$ & $38 \%$ \\
\hline
\end{tabular}




\begin{tabular}{|l|l|l|l|}
\hline $\begin{array}{l}\text { I sometimes buy } \\
\text { railway/bus tickets } \\
\text { through intermediary }\end{array}$ & $9 \%$ & $20 \%$ & $19 \%$ \\
\hline $\begin{array}{l}\text { I sometimes buy a } \\
\text { whole travel package }\end{array}$ & $14 \%$ & $23 \%$ & $31 \%$ \\
\hline
\end{tabular}

Source: Own study based on the survey conducted

Notice: The highest scores in particular categories were bolded.

A central issue in the context of selling any product is its appropriate promotion. Currently a marketing communication using Internet gains in importance within the group surveyed in terms of tourism. Therefore, the survey exploring tourism habits needed to address the question concerned with the issue. The responses provided were set out in Table 5 .

Table 5. Use of specific internet tools

\begin{tabular}{|l|l|l|l|}
\hline & Ukraine & Poland & Austria \\
\hline $\begin{array}{l}\text { Website of the region's } \\
\text { attractions }\end{array}$ & $48 \%$ & $46 \%$ & $47 \%$ \\
\hline $\begin{array}{l}\text { Website of the accom- } \\
\text { modation facility }\end{array}$ & $45 \%$ & $83 \%$ & $67 \%$ \\
\hline $\begin{array}{l}\text { Discussion forums } \\
\text { - searching for extra } \\
\text { information and rec- } \\
\text { ommendations }\end{array}$ & $33 \%$ & $49 \%$ & $31 \%$ \\
\hline $\begin{array}{l}\text { I seek for information } \\
\text { on tourism portals, } \\
\text { e.g. globtrotter }\end{array}$ & $38 \%$ & $17 \%$ & $26 \%$ \\
\hline $\begin{array}{l}\text { I use group buying } \\
\text { websites }\end{array}$ & $5 \%$ & $16 \%$ & $7 \%$ \\
\hline Tourism blogs & $50 \%$ & $13 \%$ & $19 \%$ \\
\hline $\begin{array}{l}\text { I buy flight tickets } \\
\text { on-line }\end{array}$ & $48 \%$ & $22 \%$ & $58 \%$ \\
\hline $\begin{array}{l}\text { I use the services of } \\
\text { reservation interme- } \\
\text { diaries, e.g. booking. } \\
\text { com }\end{array}$ & $29 \%$ & $13 \%$ & $22 \%$ \\
\hline $\begin{array}{l}\text { Internet mail - com- } \\
\text { munication to receive } \\
\text { extra information }\end{array}$ & $29 \%$ & $18 \%$ & $28 \%$ \\
\hline $\begin{array}{l}\text { I use facebook profile } \\
\text { of the tourism region } \\
\text { location) }\end{array}$ & $19 \%$ & $13 \%$ \\
\hline
\end{tabular}




\begin{tabular}{|l|l|l|l|}
\hline $\begin{array}{l}\text { I use facebook profile } \\
\text { of the of the accom- } \\
\text { modation facility }\end{array}$ & $14 \%$ & $23 \%$ & $17 \%$ \\
\hline
\end{tabular}

Source: Own study based on the survey conducted

Notice: The highest scores in particular categories were bolded.

As can be seen from the results a tool mostly used is a website of the accommodation facility. However, it is worthwhile mentioning that first strong differences between specific groups of respondents occur in this question, and second the findings obtained may be connected with responses to the previous question. It can be seen from the data in Table 4 that the most persons reported that they make use of intermediaries while booking accommodation. Meanwhile definitely the highest number of individuals access websites of accommodation facilities, which suggests a vast independence in selecting reservation facilities. Yet, the most students in Austria pointed out intermediaries when buying flight tickets, and at the same time definitely more individuals from that country than from other countries indicated the use of Internet to this end, which may corroborate the previous suggestion that this group is likely to regard the purchase through the Internet as an intermediary.

As previously emphasized, vast differences in the use of Internet occur among the respondents. Predominantly, widespread use of discussion forums by Polish respondents, tourism blogs by Ukrainian students and reservation systems by those surveyed in Austria should receive attention. Specifically the last tool should be brought into focus, as its use appears to be increasing, which then should be considered by the managers of accommodation facilities.

Table 6. Barriers constraining travelling opportunities

\begin{tabular}{|l|l|l|l|}
\hline Barrier & Ukraine & Poland & Austria \\
\hline No money & $83 \%$ & $76 \%$ & $74 \%$ \\
\hline Household obligations & $12 \%$ & $25 \%$ & $30 \%$ \\
\hline Health condition & $7 \%$ & $6 \%$ & $7 \%$ \\
\hline $\begin{array}{l}\text { Professional obliga- } \\
\text { tions }\end{array}$ & $26 \%$ & $43 \%$ & $32 \%$ \\
\hline No desire to travel & $12 \%$ & $4 \%$ & $4 \%$ \\
\hline No holiday leave & $31 \%$ & $29 \%$ & $28 \%$ \\
\hline $\begin{array}{l}\text { I rested in the place of } \\
\text { residency }\end{array}$ & $2 \%$ & $14 \%$ & $8 \%$ \\
\hline
\end{tabular}

Source: Own study based on the survey conducted

Notice: The highest scores in particular categories were bolded. 
The last element surveyed was constraint travelling opportunities (Table 6). It should not come as a surprise, particularly considering sampling, that no money garnered highest scores. Students as a group have free time in their disposal, though they largely do not work. This barrier affects the Ukrainian group more than Polish or Austrian respondents. In the compilation outlined two issues should receive attention, they appear to be tremendously significant, and they reveal differences across groups under survey. In the group of the Ukrainian respondents constraints concerned with household obligations and professional obligations are less marked. Regarding the latter barrier it comes into the foreground in the Polish group. Principally, it may be ascribed to the higher average age among Polish respondents, and thus taking a professional job. Furthermore, it is apparent that Polish students generally begin their work sooner. Remaining barriers occur more seldom, and even when strong percentage differences emerge among respondents' groups they have weaker implications for the tourism demand.

\section{Findings and discussion}

Certainly tourism should be regarded as a significant economic sector, and its role in triggering economic growth across numerous regions should be appreciated. At the same time it should be kept in mind that, as shown above, in practice there are highly diversified tourism forms driven by multiple motives and varied consumer-tourist preferences. As a consequence the immense diversity of stimulants propelling tourism demand flourish, thereby strongly affecting and diversifying tourism products.

Tourism managers as well as those charged with creating demand for services of a specific enterprise need to take hold of this diversity in their operations at a national, regional and local level. Overall, it is difficult, if not impossible, to prepare a universal product so as to satisfy needs among various consumer groups. Therefore, on the market surveyed its appropriate segmentation gains particular importance. Meanwhile, to identify the required segment and then design a product intended to satisfy its needs with top quality, it is necessary to investigate consumer habits and preferences. To this end, the survey was carried out.

On the whole, students represent a group manifesting explicit specifics. It is a community of young persons, enjoying a fairly extensive knowledge, disposing an immense quantity of leisure time, having relatively low family and labour obligations, and at the same time it lacks high budgets. As posed by the primary research hypothesis, even this group was internally diversified. The current study found numerous presumptions for demonstrating differences among students from three various countries: Poland, Ukraine and Austria. The core presumptions are as follows:

- the most common forms of spending free time across all groups, which should 
not come as a surprise, is recreation and sightseeing, yet even the findings in this area reveal differences; for instance recreation on the beach was reported by $77 \%$ of Poles, whereas merely $52 \%$ by Ukrainians;

- considerable differences among groups were evident in assessment of factors determining travel decisions, though the cost was the key driver across all groups, differences in the assessment of other factors stood at $30-40 \%$;

- across groups surveyed, intermediaries are used in various manners, e.g. students in Austria indicated purchase of flight tickets through intermediaries on a more frequent basis than Poles and Ukrainians;

- all groups surveyed claimed that they heavily used Internet tools, but they did so in a different manner, e.g. Poles are more eager to utilize discussion forums, while students from Austria more frequently use reservation systems such "booking.com".

To conclude, it should be kept in mind that the findings produced should be approached with some caution. Overall, this was a research survey and groups of respondents were limited. Yet, differences across specific groups were distinctive so that they could not be caused by sampling or a statistical error. Consequently, while managing any tourism product, attention should be drawn to differences between consumers. On the other hand, adjusting the product to the expectations of any group may lead to a specific conflict, and such measures may result in the dissatisfaction of another group. In many situations differences in expectations may be hard to be reconciled, e.g. in the case of the hotel which develops its infrastructure for families with kids may disturb persons seeking for peace and quiet.

At the same time it appears that there is the need to continue research in the foregoing area. Certainly, it would be expedient to carry out surveys across a group broader than students. Due to the current situation in Ukraine it is necessary to consider how much tourism lost its relevance among consumer expenditures in the country. Moreover, it should be also underlined that the survey solely indicated certain behaviours in specific consumers' groups, and thus it would be advisable to make further inquiries on the motives propelling tourists behaviours. The research area presented is the domain subject to dynamic shifts, and therefore provides numerous opportunities for researchers.

\section{References}

Bosiacki, S., Sikora, J, Śniadek, J., Wartecki, A.(2008), Zarzqdz̨anie prz̨edsiębiorstwem turystycznym, Poznań, Akademia Wychowania Fizycznego im. Eugeniusza Piaseckiego w Poznaniu.

Celtek, E. (2013), Experiental marketing in a tourism destination: selected theoretical aspects, Zeszyty Naukowe Uniwersytetu Szczecinskiego. Scientific Journal. Service Management, vol. 10 , pp. 5-17. 
Cooper, C., Fletcher, J., Gilbert, D., Wanhill S. (1998), Tourism. Principles and practice, New York, Longan.

Gaworecki, W. (2007), Turystyka, Warszawa, Polskie Wydawnictwo Ekonomiczne.

Gryszel, P. (2004), Regionalne i lokalne organizacje turystyczne jako instytucje wspierajace rozuwój regionalnego produk.tu turystycznego, in Panasiuk A., (ed.) Markowe produk.ty turystyczne, Szczecin, Uniwersytet Szczeciński, Szczecin 2004.

Holloway, J. (2002), The business of tourism, Harlow, Pearson Education, Harlow.

Hannam, D., Knox, D. (2010), Understanding tourism. A critical introduction, London Sage Publications.

Kaczmarek, J., Stasiak, A., Włodarczyk, B. (2010), Produkt turystyczny. Pomysł, organizacja, zarzadzanie, Warszawa, Polskie Wydawnictwo Ekonomiczne.

Kiralova, E. (2003), Marketing destinace cestovnicho ruchu, Praha, Ekopress.

Kizielewicz, J. (2014), Zachowania nabywcze turystów wypoczywających w strefie nadmorskiej Wybrzeża Gdańskiego, Zeszyty Naukowe Uniwersytetu Szczecińskiego no 805, Ekonomiczne Problemy Turystyki vol. 25, no 1, pp. 285-308.

McCabe, S. (2010), Marketing Communications in Tourism and Hospitality. Concepts, strategies and cases, Oxford, Butterworth-Heinemann.

Meyer, B. (2008), Gospodarka turystyczna i przemyst turystyczny, in Panasiuk A. (ed.) Gospodarka turystyczna, Warszawa, Wydawnictwo Naukowe PWN.

Panasiuk, A. (2014), Rynek turystyczny. Studium strukturalne, Warszawa, Difin.

Sung, K. (2013), Community Destination Management In Developing Economies, New York, The Haworth Press.

Tourism terminology - recommendations by WTO (1995), Warszawa, Wydawnictwo Instytutu Turystyki-ONZ-WTO.

UNWTO Tourism Highlights 2014, UNWTO.

Vassiliadis, C. (2008), Destination Product Characteristics as Useful Predictors for Repeat Visiting and Recommendation Segmentation Variables in Tourism: a CHAID Exhaustive Analysis, International Journal of Tourism Research, vol. 10, no5, pp. 439-452.

Yoon, Y., Uysal, M. (2005), An examination of the effects of motivation and satisfaction on destination loyalty: a structural model. Tourism Management. vol. 26, no 1, pp. 45-56.

Van der Merve, P., Slabbert, E., Saayman, M. (2011), Travel Motivations of Tourists to Selected Marine Destinations, International Journal of Tourism Research, vol. 13, no. 5, pp. 457-467. 
